\title{
Sex Tourism in Digital Age, A Dark Side of Paradise, Bali Indonesia
}

\author{
By Ashikul Hoque, Mohammad Waliul Hasanat, Ishtiaque Arif \\ \& Prof. Abu Bakar Abdul Hamid
}

Abstract- The research paper is aiming at identifying the dark side of Bali and the reason behind the growth of its sex tourism industry in this digital era. The main focus of this research paper is the process by which the digitalization supports stimulating sex tourism in Bali. The researcher is focusing on executing the secondary form of research method to collect necessary data. The data gathering process is carried out with the help of news articles and journals of the previous researches. With the help of the collected information, the researcher can ful fill the research questions with the help of representing the facts in the results and analysis section. The research is also focusing on the limitations of this research study and the conclusion section provides stress on those limitations.

Keywords: sex tourism, child sex tourism, prostitution, bali.

GJMBR-E Classification: JEL Code: M19

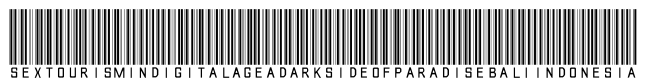

Strictly as per the compliance and regulations of:

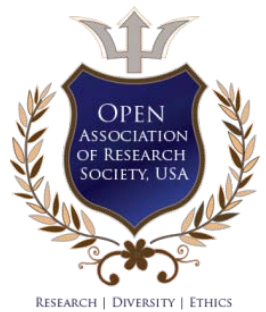

(c) 2020. Ashikul Hoque, Mohammad Waliul Hasanat, Ishtiaque Arif \& Prof. Abu Bakar Abdul Hamid. This is a research/review paper, distributed under the terms of the Creative Commons Attribution-Noncommercial 3.0 Unported License http://creativecommons.org/licenses/by-nc/3.0/), permitting all non-commercial use, distribution, and reproduction in any medium, provided the original work is properly cited. 


\title{
Sex Tourism in Digital Age, A Dark Side of Paradise, Bali Indonesia
}

\author{
Ashikul Hoque ${ }^{\alpha}$, Mohammad Waliul Hasanat ${ }^{\sigma}$, Ishtiaque Arif ${ }^{\rho}$ \& Prof. Abu Bakar Abdul Hamid ${ }^{\omega}$
}

Abstract- The research paper is aiming at identifying the dark side of Bali and the reason behind the growth of its sex tourism industry in this digital era. The main focus of this research paper is the process by which the digitalization supports stimulating sex tourism in Bali. The researcher is focusing on executing the secondary form of research method to collect necessary data. The data gathering process is carried out with the help of news articles and journals of the previous researches. With the help of the collected information, the researcher can fulfill the research questions with the help of representing the facts in the results and analysis section. The research is also focusing on the limitations of this research study and the conclusion section provides stress on those limitations.

Keywords: sex tourism, child sex tourism, prostitution, bali.

\section{INTRODUCTION}

a) Background of the research

- he tourism industry has witnessed a substantial level of growth in the last few decades. The globalization of this industry has stimulated growth. In this context, the global tourists are exploring many global tourism destinations. Currently, Bali in Indonesia is regarded as one of the most popular tourist destinations. The place is overwhelmingly well-liked for its exotic locations and scenic beauty. However, the discussed attraction of Bali is its nightlife. Bali is becoming famous for its sex industry, which boosts the tourism industry of this place. The sex tourism industry in Bali has flourished day by day, and many male and female sex workers are earning their living on this island (Alcano, 2017). The sex tourism influences the growth of prostitution, sex trafficking, and sexual violence in society. The recognition as Sex Island hampers the image of the Island and reputation of the citizens of the island. In this context, it is significant to investigate the influential factors, which fuel the sex industry in Bali to control it.

\section{b) Research Aims and Objectives}

The study aims to identify the dark side of Bali and the reason behind the growth of its sex tourism industry and how the digitalization stimulates the island's sex tourism. The objective of the study is to recognize whether the sex tourism is the dark side of Bali or not.

c) Research Question

Is sex tourism a dark side of Bali in this digital age?

Author a: e-mail: ashikul.phd_mgt18@grad.putrabs.edu.my

\section{il. Literature Review}

Bali is very renowned for its Nightlife parties. In these parties, numerous amounts of residents and tourists came for entertainment purposes. Prostitution is a sinful crime against moral ethics and civility. However, in Bali, sex tourism is broadly practiced. The survey and observation results show that some women are becoming a part of sex tourism due to poor financial conditions. Travel agencies and sex magazines are significantly promoting sex tourism through brochures. For sex tourism, the arrangers involve in the supply of several facilities for the residents and tourists. Among these arrangements, accommodation and transportation are two important aspects of sex tourism (Bali, 2018). The sex tourism network has been operated across national boundaries also. The sex tourism industry tries to integrate the numbers of institutions to expand their activities. In Thailand, millions of tourists are coming regularly. The main aim of sex tourism is to minimize the uncertainties that can create dissatisfaction among tourists. Female prostitution is a provision of sexual services against payment. In a word, sexual services are a part of the exchange relationship.

Sex tourism is using social media sites to attract the attention of the clients. For serving the needs of the clients, the sex tourism industry has taken this type of initiative. However, the involvement of children in sex tourism is creating a significant issue in Indonesia. The people are entering in the sex tourism industry due to earn quick money. Among the people of the sex industry, most of them are from underprivileged, deprived families and middle-class families. There are several numbers of people exist who are involving in sex tourism intentionally. But, several numbers of people are becoming prostitute due to external forces. In most cases of forced prostitution, the family members are responsible. In Bali, by different genders, ages, and sexes practice prostitution. In Bali, male sex workers are referred to as the Kuta Cowboys (Lo, 2019). The male sex workers are involving in providing sex services to foreign tourists. The sexual orientation is a very imperative factor that helps to understand the activeness of the sex workers in Bali. The numbers of heterosexual prostitution are highest among the sex workers under the sex tourism industry. Apart from this, gay and cross-dresser prostitutes are also available in Bali. In this sex heaven, the sex workers are available in 
karaoke rooms, massage parlors, and discotheques. The clients can be able to book sex workers via telephone (Putra \& Hitchcock, 2017).

Child sex tourism is widespread in Bali. As per the organization named ECPAT Indonesia is one of the most popular nations for its sex tourism industry. Based on the research carried out by this organization, it is evident that the rules and regulations related to child sex tourism in Indonesia are generally violated in this country. The Child protection policies at the national level are not appropriately maintained in Indonesia. Due to this reason, the Indonesian government formulated Anti Sex Crimes against children through the help of establishing national movement. The child prostitutes are available easily in the bars, cafes, nightclubs, hotels, and spas present in Bali. Another emerging trend that is related to this context is sexual transactions (Ecpat, 2015). Some of the dealers present in the Bali region in Indonesia are involved in providing their apartments for sexual entertainment. Online prostitution is also practiced in this region. The sexual activities are day by day increasing as the local government and the local government officials are involved in this process. Though the national government has developed strict rules and regulations execution of those rules and regulations is not appropriate due to the influence established on the local government through the prostitute dealers. The increasing rate in child sex tourism is an alarming issue in the region of Bali. The impact of the tourism environment on the city is responsible for the creation of a negative image of this city. The negative image of the city develops due to this process. The tourists are reducing their visits to seeing this process. As a result of child prostitution, the impact drops on the children's education process. The impact made on the child's growth environment and surroundings (Ecpat, 2016).

\section{Methodology}

The researcher is aiming at gathering the secondary data for executing this research process. The secondary data will be obtained with the help of collecting the data from the previous researches carried out by the researchers. The secondary data is tried and tested data that was previously analyzed and filtered by different researchers. The secondary form of the data gathering process is a fast and easy process of data collection. The researcher is aiming at gathering this process to gain a broader understanding of the subject matter. The secondary research is also a quick process of data gathering. Hence, the secondary data is used by the researcher to investigate and explore the gathered data appropriately (Question Pro, 2018). Different steps will be followed by the researcher for the collection of the data. These steps are as following points:-
- Firstly, the researcher will identify the research topic. The identification of the research topic will help the researcher to provide the necessary focus on the subject that needs to be researched. The enlistment of the research attributes related to the topic will run by focusing on the purpose of the research (Question Pro, 2018).

- Secondly, the researcher will gather the resources from the different journals, news and media articles for gathering the relevant data for the research. The information will be gathered by narrowing down the information sources.

- Thirdly, the researcher will run the process of collection of existing data. The data related to the research will obtain from different newspapers, public libraries, and journal sources. The government and the non-government information will be considered by the researcher to execute the research.

- Lastly, the analysis of the data collected will run based on the research question prepared by the researcher. It will help the researcher to meet the research objectives prepared at the initial stage (Question Pro, 2018).

The researcher will use this process of gathering data as it is less time consuming and less expensive. It will be supportive for the researcher in easily gathering the data. The minimum expenditure is associated with obtaining the data needed for executing the research.

\section{Results and Discussion}

Based on the question prepared by the researcher, the data gathered by the researcher is from ECPAT Indonesia and other journals. For the ECPAT Indonesia, the researcher has gathered information related to the sexual exploitation of children in the travel and tourism industry in Indonesia. Based on the collected data, it is reflecting the sex tourism is carried out mainly in the form of child prostitution, boy prostitution, and pedophilia. These forms of sex tourism processes are common in Bali. The researcher also identified the factors that are leading to the involvement of prostitution. The participation of prostitution is including the broken family, consumerism, and free sex. The process of prostitution is carried out over mobile phones, messaging services, and social media processes (Suwung, 2017). The other forms of child sex tourism identified by the researcher in Bali are pedophilia. It is including the foreigners who are present in this process. Initially, sex victims were between the ages of eight to 15 years. The pedophiles preferred to target the girls who are present in the stage of early puberty or menstruation. The agents usually target the pedophiles for having greater sexual gratification. The 
pedophiles also prefer to have the boys by whom they can recruit other boys by grooming them. These processes are common in some areas such as Karangasem, Buleleng, and Denpasar (Tajeddini \& Ratten, 2017). The child prostitute process is also common in other areas such as Java Island, Banyuwangi and Bandung. This evidence represented by the researcher is helping in proving that sex tourism is a dark side of Bali. Even the children are targeted for continuing this process in this digital age. Due to this reason, the secondary research undertaken by the researcher is fruitful to a great extent as it is proving the research objectives and the research question.

\section{Conclusion}

The overall research is focusing on the analysis of sex tourism that is a dark side of Bali. The investigation study is reflecting that prostitution cannot be viewed solely from the perspective of tourism. The study is also illustrating that sex tourism is becoming a dark side for Bali in this digital era. Due to this reason, the impacts on the trade processes are examined that is due to the development of child sex tourism and other processes of prostitution and this impacts the international tourism processes. The analysis is focusing on the views that child sex tourism is increasing in the Bali region of Indonesia. The reason for becoming a prostitute is explained in the results and analysis section. It is extremely emphasizing on the activities that are proving that how the children and other male and females are dragged into the prostitution process (Ecpat, 2016). The impact drops on the new generation, and also the social environment is destroyed in Bali as per the research showed. The limitations of this research are that the qualitative and quantitative process of conducting the research process does not undertake. Without this process, the researcher is not able to produce an in-depth analysis of the situation for proving the research objectives.

\section{References Références Referencias}

1. Alcano, M. (2017). Male Sex Work in South Bali: Bodies, Violence, and Entrepreneurship. Retrieved 21 October 2019, from https://link.springer.com/ch apter/10.1057\%2F9781137541468_4

2. Bali. (2018). Bali Nightlife after Dark, the Bali Girls, and drugs. Retrieved 21 October 2019, from https://www.bali.com/nightlife.html

3. Ecpat. (2015). Status of action against commercial sexual exploitation of children. Retrieved 21 October 2019, from https://www.ecpat.org/wp-content/upl oads/2016/04/a4a v2 eap indonesia.pdf

4. Ecpat. (2016). Glōbal Study on Sexual Exploitation of Children in Travel and Tourism. Retrieved 21 October 2019, from https://www.ecpat.org/wpcontent/uploads/2016/10/3.-SECTT-INDONESIA.pdf
5. Lo, H. (2019). Bali Sexual Assault Raises Liability Question for Travel Agents. Retrieved 21 October 2019, from https://www.sixthtone.com/news/1003 944/bali-sexual-assault-raises-liability-question-fortravel-agents

6. Putra, N., \& Hitchcock, M. (2017). Terrorism and Tourism in Bali and Southeast Asia. Retrieved 21 October 2019, from http://www.niaspress.dk /files/excerpts/Hitchcock_extract.pdf

7. Question Pro. (2018). Secondary ResearchDefinition, Methods and Examples. | Question Pro. Retrieved 21 October 2019, from https://www.questi onpro.com/blog/secondary-research/

8. Suwung, S. (2017). A Short History of Bali Indonesia. Retrieved 21 October 2019, from https://www.academia.edu/22406954/A_Short_Histo ry_of_Bali_Indonesia

9. Tajeddini, K., \& Ratten, V. (2017). Female tourism entrepreneurs in Bali, Indonesia. Retrieved 21 October 2019, from https://www.researchgate.n et/publication/310649286_Female_tourism_entrepre neurs in Bali Indonesia 